\title{
Otto F. A. Meinardus, Two Thousand Years of Coptic Chri- stianity, The American University in Cairo Press, Cairo 1999, ss. 344.
}

Wśród historiografii kościelnej nie brakuje pozycji dotyczącej chrześcijaństwa w Egipcie, przede wszystkim Kościoła koptyjskiego. Pomimo że Kościół koptyjski liczy kilka, maksymalnie dziewięć-dziesięć milionów wiernych, zainteresowanie tym Kościołem jest wciąż żywe. W latach siedemdziesiątych XX wieku powstało nawet międzynarodowe towarzystwo naukowe pod nazwą International Association for Coptic Studies, które sukcesywnie co 4 lata organizuje międzynarodowe kongresy w różnych miastach świata, na które przybywają uczeni zajmujący się sensu largo koptologią z całego świata.

Jedną z postaci, która w historiografii Kościoła koptyjskiego w XX wieku zajmuje znaczące miejsce, jest Otto F. A. Meinardus, niemiecki specjalista z zakresu chrześcijaństwa egipskiego, ściśle współpracujący z The American Univeristy in Cairo ${ }^{1}$. Jego prace o charakterze naukowym i popularno-naukowym są zawsze dobrze przyjmowane, szczególnie przez badaczy pracujących w Egipcie 2 .

Nakładem The American University in Cairo Press ukazała się kolejna pozycja tego Autora. Ma ona charakter przekrojowy, posiada układ problematyczno-chronologiczny i składa się z trzech rozdziałów, czterech aneksów, bibliografii $\mathrm{i}$ indeksu.

Recenzowana pozycja jest kompilacją dwóch poprzednich książek Otto F. A. Meinardusa: Christian Egypt, Ancient and Modern (Cairo wyd. 1 1965, wyd. 2 1977) oraz Christian Egypt, Faith and Life (Cairo 1970).

Przełom dwóch tysiącleci spowodował liczne refleksje nad dokonaniami cywilizacji, społeczeństw, kultur i religii. Autor recenzowanej pozycji w rozdziale pierwszym pt. Toward the Third Millenium nawiązuje do tego wątku poprzez krótki opis dziejów Kościoła koptyjskiego drugiej połowy XX wieku, która była zdominowana przez politykę obecnego papieża Szenudy III. Drugą przyczyną napisania tej pozycji było, jak się zdaje, zebranie się synodu Kościoła koptyjskiego w $1998 \mathrm{r}$.

Dopiero w kolejnym rozdziale Autor zajął się historią, tradycją, teologią i strukturą Kościoła koptyjskiego. W wielkim skrócie zostały potraktowane początki tego Kościoła. W tle zostały zarysowane początki chrześcijaństwa, ze szczególnym uwzględnieniem pobytu świętej rodziny w Egipcie. Bardzo pobieżnie i niedokładnie opisuje Autor okres, który jest dobrze opisany w historiografii,

\footnotetext{
1 Jest to największy uniwersytet amerykański na terenie Afryki i Bliskiego Wschodu.

2 Do najważniejszych publikacji książkowych tego autora należy zaliczyć: The Copts in Jerusalem, Cairo 1960; Monks and Monasteries of the Egyptian Deserts, Cairo 1961 (późniejsze wydania: 1989, 1992); Christian Egypt: Faith and Life, Cairo 1970; Christian Egypt: Ancient and Modern, Cairo 1977; The Holy Family in Egypt, Cairo 1986.
} 
inwazji arabskiej na teren Egiptu w 641 roku. Cytaty z dzieł historycznych nie mają odpowiedniego oznaczenia stron i wydania, jak np. w cytacie z Historii Patriarchów Aleksandryjskich (s. 30-31) brak jest nie tylko stron cytowanego ustępu, ale również oznaczenia wersji, z której Autor korzystał (dla historyka powinna być to kwestia istotna).

Więcej miejsca od opisu historii Kościoła koptyjskiego zajmuje problematyka związana z teologią. Autor podjął się trudu wyjaśnienia korzeni kościoła koptyjskiego przez pryzmat sporów chrystologicznych, jakie miały miejsce w IV i V wieku. W ramach tego opisu Otto F. A. Meinardus dokonał przeglądu kanonów Kościoła koptyjskiego. Niestety nie zostało wyjaśnione, które teksty kanonów zostały włączone do prawa kanonicznego tego Kościoła, które są obowiązujące, etc.

Do tła historycznego Autor dołączył także krótkie opisy ważniejszych soborów i synodów kościelnych. Jednakże opisy te prezentują się nader skąpo, brak jest chociażby zasygnalizowania ważniejszych problemów podejmowanych przez uczestników tych spotkań (poza opisem soboru w Chalcedonie, który był przyczyną podziału Kościoła, również na terenie Egiptu, s. 53-54)3. Czytelnik może także odnieść wrażenie, że wątek soborów i synodów jest zbędny, ponieważ trudno jest odnaleźć czasami odniesienia postanowień poszczególnych soborów do Kościoła koptyjskiego.

Najwięcej miejsca Autor poświęca historii XIX i XX wieku, co chyba jest odzwierciedleniem stosunku wiedzy o czasach bardziej współczesnych niż o dawniejszych. Czytelnik ma prawo spodziewać się poważniejszego potraktowania szczególnie czasów, kiedy Kościół ten się rodził, czy chociażby okresu, kiedy przechodził głęboki kryzys pod „okupacją” arabską.

Połowę pracy stanowią zawarte w rozdziale trzecim („The Coptic Church: Its Churches and Monasteries", s. 143-264) opisy poszczególnych kościołów i klasztorów. Ta część może przypominać Czytelnikowi bardziej przewodnik z krótkim rysem historycznym poszczególnych budynków sakralnych niż pozycję naukową, czy nawet pretendującą do miana popularno-naukowej. Tytuł sugeruje problematykę związaną z kryzysami w łonie Kościoła lub specyficzną sztukę sakralną, którą ze względu na jej oryginalność zaczyna się nazywać „koptyjską” etc. Jednak kilkuzdaniowe wypowiedzi na temat poszczególnych kościołów czy monasterów nie korespondują, w moim przekonaniu, z tytułem prezentowanej pracy.

Na uwagę zasługują aneksy. W pierwszym z nich Autor podaje listę imion używanych przez Koptów (choć niewywodzących się z koptyjskiego) z ich znaczeniem oraz etymologią. W drugim przedstawił listę patriarchów Kościoła kop-

3 Od tzw. przełomu chalcedońskiego do dziś istnieją w Egipcie dwa patriarchaty aleksandryjskie (grecko-ortodoksyjny (uznający Chalcedon) oraz patriarchat koptyjski nieakceptujący postanowień soboru w Chalcedonie). 
tyjskiego począwszy od św. Marka do obecnego Szenudy III. Zabrakło tu informacji o pochodzeniu patriarchów. Nie ma wzmianki choćby o tym, że prawdopodobnie pierwszym patriarchą pochodzenia koptyjskiego był dopiero Benjamin I (623-662 r.), a do tego czasu zostawali nimi ludzie przeważnie pochodzenia greckiego.

Cenną rzeczą jest umieszczony na końcu książki kalendarz, w którym zawarto spis świąt koptyjskich. Ponieważ różni się on od kalendarza juliańskiego czy gregoriańskiego, Autor podaje odpowiedniki w trzech kalendarzach, co ułatwia orientację.

Książka posiada także fotografie ważniejszych miejsc dla Koptów, chociaż brak jest fotografii z dzielnicy koptyjskiej Kairu, Babilonu.

Prezentowana książka stanowi kolejny krok ku upowszechnieniu wiedzy o rdzennym społeczeństwie Egiptu.

Wojciech Walczak Białystok 